\title{
"The Force that Keeps you Going": Enthusiasm in Vocational Education and Training (VET) Teachers' Work
}

\author{
Sanna Wenström*1, Satu Uusiautti², and Kaarina Määttä ${ }^{2}$ \\ ${ }^{1}$ Luovi Vocational College, Nahkatehtaankatu 3 Oulu, Finland \\ ${ }^{2}$ University of Lapland, P.O. Box 122, 96101 Rovaniemi, Finland
}

Received: 11.01.2018; Accepted: 12.07.2018; Published: 17.12.2018

\begin{abstract}
Context: Enthusiasm has been noted to increase productivity and quality at work. In teachers' work, this has a connection to student learning and motivation, as well as teaching quality. In the context of Finnish vocational education and training (VET), research on enthusiasm appears especially topical and relevant because of the ongoing wide reform with emphasis on productivity and efficiency.

Approach: In this study, Finnish VET teachers' enthusiasm at work was studied qualitatively. Three research questions were set for this study: (1) How do VET teachers describe their enthusiasm?; (2) What factors strengthen their enthusiasm, according to their descriptions?; and (3) What factors weaken their enthusiasm, according to their descriptions? Altogether, 103 teachers who voluntarily participated in the study completed an online questionnaire on enthusiasm. The data were analyzed through qualitative content analysis.

Findings: According to the results, the teachers who participated in the study were very interested in their work. They wanted to share how they experienced enthusiasm in their work. Their enthusiasm manifested as their willingness to develop their skills and expertise. It also showed in their dedication, good job performance, and positive feelings about their work. Student encounters, a positive atmosphere, and work interactions were the main sources of enthusiasm. Lack of resources, changes, cuts in the VET budget, and a lousy work atmosphere weakened enthusiasm.
\end{abstract}

\footnotetext{
${ }^{*}$ Corresponding author: Sanna.Wenstrom@oamk.fi
}

ISSN: 2197-8646

http://www.ijrvet.net 
Conclusions: The study found that enthusiasm manifested itself in ways that correspond well with the current VET productivity and efficiency goals. Because enthusiasm was strengthened especially when teachers were working with students, it seems important to ensure a supportive work environment for students also after the VET reform. Positive interactions, collegial support, and working together can help teachers to succeed and to maintain enthusiasm in their everyday work. According to the results of this study, supervisors may play a central role in facilitating teacher enthusiasm.

Keywords: VET, Vocational Education and Training, Teacher, Enthusiasm, Work Engagement, Vocational Education

\section{Introduction}

The speed of the changes in the workplace presents unprecedented challenges for vocational education and training (VET) currently. This naturally concerns VET teachers, too. The central task of vocational education is to produce workers with high levels of expertise and to support life-long learning and professional growth (Law on vocational education 531/2017, $2 \S$ ). Today's employees cannot expect to just keep doing the same tasks and to stay in the same job for decades. These demands influence VET teachers' work greatly - from the way they perceive their job and its changing nature and the way they prepare students for the workplace. Enthusiastic experts are needed in today's workplaces (e.g., Zhu \& Engels, 2014), which is one the goals that the reform of Finnish vocational upper secondary education is going to respond. Where is enthusiasm found in teachers' work?

Enthusiasm is one of the factors in work engagement, or it can be merely a form of work engagement (Hakanen, Bakker, \& Schaufeli, 2006). Kunter and Holzberg (2014) has defined engagement as positive affective motivational fulfillment, which includes the aspect of enthusiasm. Enthusiasm is a personal experience of feeling energetic and inspired at work (Barsade \& Gibson, 2007; Russell, 1980; Warr, 1990). The manifestation of enthusiasm has been described as "conjoined occurrence of positive affective experiences" and "enjoyment" (see e.g., Keller, Woolfolk Hoy, Goetz, \& Frenzel, 2016, p. 751). The term "employee engagement refers to the individual's involvement and satisfaction with as well as enthusiasm for work" (Harter, Schmidt, \& Hayes, 2002, p. 269). In general, enthusiasm is often linked to engagement, which in turn has been noted to have a positive influence on, for example, productivity in organizations (Harter et al., 2002; Xanthopoulou, Bakker, Demerouti, \& Schaufeli, 2009b) and personnel well-being (Hallberg \& Schaufeli, 2006; Schaufeli, Taris, \& Van Rhenen, 2008; Uusiautti \& Määttä, 2015).

The effects of enthusiasm have been studied in the work of teachers at various education levels (e.g., Keller et al., 2014; Kunter et al., 2013; Patrick, Hisley, \& Kempler, 2000). In sum, teacher enthusiasm has a positive influence on student learning, performance, and motivation (Keller, Neumann, \& Fisher, 2013; Kunter et al., 2013; Patrick et al., 2000), and on teaching quality (Frenzel, Goetz, Lüdtke, Pekrun, \& Sutton, 2009; Kunter et al., 2011; 2013). An enthusiastic teacher promotes enthusiasm in students (Frenzel, 2008; Frenzel et al., 2009). 
The most extensive reform of vocational education (later referred as the reform) is currently taking place in Finland as degree requirements, legislation, and funding systems are being overhauled (Minedu, 2017). This reform updates the entire vocational education and training (VET) by 2018. As part of this reform, the funding provided for vocational education units will be dependent on student graduation rates, employment success, and post-secondary education - in other words, education effectiveness. At the same time, the workplace needs enthusiastic employees who are willing to develop the job and their own expertise (see e.g., Uusiautti, 2017). Due to the comprehensive reform in the Finnish vocational education, the findings from the aforementioned studies seem promising from the perspective of vocational education: enthusiastic teachers can boost students' enthusiasm about the field they are studying and about their future occupation. Considering these demands on VET teachers' work, we found it reasonable to examine how they describe their enthusiasm and to determine what could be learned from their experiences.

The purpose of this research was to analyze VET teachers' enthusiasm at work and the factors influencing it, based on their own perceptions. Therefore, the purpose was to "learn" from teachers' subjective experiences and to hear their voices to make conclusions about, for example, how to help them to maintain their enthusiasm, instead of just analyzing enthusiasm at the levels of behaviors or teaching styles (see Kunter et al., 2011).

\section{Theoretical Background}

Teacher enthusiasm has been studied in the form of displayed enthusiasm and as experienced enthusiasm (Keller et al., 2016). Expressed enthusiasm refers to teachers' interactions and teaching styles as well as to non-verbal communication and presentation in teaching situations (Keller et al., 2016). Experienced enthusiasm means being inspired about the subject one is teaching and being inspired about teaching in general (Keller et al., 2016).

Teacher enthusiasm has been described as an emotional orientation to work that appears in teaching situations and is based on the experienced sense of joy and pleasure in teaching or the subject area (Kunter et al., 2011). However, the concept of enthusiasm seems to need further specification and analysis (Keller et al., 2016). As mentioned, in this study, enthusiasm is regarded as an aspect of work engagement, which includes both emotional and cognitive dimensions (Bakker, 2011; Keller et al., 2016; Schaufeli, Salanova, González-Romá, \& Bakker, 2002).

Work engagement can be defined as a wide-spread positive state that does not focus on just one thing, event, or behavior (Schaufeli, \& Bakker, 2004), such as a school subject or teaching situation. This perspective is crucial to this study because VET teachers' work is not limited to teaching student groups in classrooms. Instead, vocational education reform in Finland necessitates that VET teachers' work increasingly involve serving as guides and supporters of VET students and their learning processes. Teachers have to work in multi-professional networks, in collaboration with workplaces, and as developers of their own vocational fields and pedagogy (Vähäsantanen, 2015; Vähäsantanen, Saari- 
nen, \& Eteläpelto, 2010). Furthermore, teachers work as members of their educational institutions, and this also influences their enthusiasm levels (Keller et al., 2016).

The factors that influence and the means to increase teacher enthusiasm have not received much attention (Keller et al., 2014; 2016). This study adds a new perspective by analyzing teacher enthusiasm as a part of work engagement (Bakker \& Demerouti, 2007; Demerouti, Bakker, Nachreiner, \& Schaufeli, 2001). Even though teachers' resources have been studied (Hakanen et al., 2006), their enthusiasm as an aspect of the definition of work engagement has not been previously analyzed.

This kind of research is important also because previous studies on enthusiasm and work engagement have used mostly quantitative methodological approaches; thus, analyses have focused on pre-determined variables (Bakker \& Bal, 2010; Hakanen et al., 2006; Salanova, Bakker, \& Llorens, 2006). Therefore, the purpose of this study is to obtain essential information about teacher enthusiasm through teachers' own definitions of this element of work engagement (Creswell \& Miller, 2000; Josephson \& Vingård, 2007; Keller et al., 2016).

Furthermore, this study is targeted specifically at VET teachers, who have been a less-studied group in research on teachers and on work engagement (see e.g., Bakker et al., 2007; Hakanen et al., 2006; Kunter et al. 2008; 2011). This study is also very topical because it was conducted at the threshold of Finnish VET reform (data collection in 2016-2017; legislation reforms came into effect Jan 1, 2018).

\section{Methods}

The purpose of this research was to study Finnish VET teachers' enthusiasm at work and to understand the factors that strengthened or weakened their enthusiasm by listening to their voices. The following are the research questions for this study:

- How do VET teachers describe their enthusiasm?

- What factors strengthen their enthusiasm, according to their descriptions?

- What factors weaken their enthusiasm, according to their descriptions?

This was a qualitative study (Lichtman, 2013; Thomas, 2006) aimed at gaining a description and a deeper understanding of the phenomenon under study (Lichtman, 2013). The phenomenon of enthusiasm was described by the teachers themselves; therefore, the emphasis was on discovering their viewpoints and perceptions (Cozby \& Bates, 2012; Denzin \& Lincoln, 2003; Keller et al., 2016). Qualitative research gives voice to research participants and tries to describe and to interpret phenomena that cannot be directly observed (Cohen, Manion, \& Morrison, 2011). The fundamental idea is that the social reality is always complex, multi-layered, and contradictory (Cohen et al., 2011). From the perspective of work and organizations, qualitative research increases our understanding about how people think, feel, and behave at work. This was useful for facilitating and studying employee motivation, well-being, and organizational change and development (Doldor, Silvester, \& Atewologun, 2017). 
This was a data-driven study, which means that the theoretical information facilitated the analysis and structuring of the findings, but it was not used for categorizing the concepts prior to the analysis. This kind of approach is relevant especially if there is little or no information about the topic under investigation.

The research participants comprised 103 Finnish VET teachers. The data were obtained in two phases - in May 2016 and November 2016-March 2017 through an electronic questionnaire by using convenience sampling (Patton, 2002). The internet link for the questionnaire was disseminated to suitable research participants through various networks and social media. First, the questionnaire was sent to vocational education teachers $(\mathrm{N}=40)$ through the vocational education development network, in which the author of this article was involved. The teachers were asked to forward the questionnaire to other VET teachers. In addition, the questionnaire was submitted to the members of the Finnish VET teacher organization through social media. In all, there are about 10,000 VET teachers in Finland, but everyone is not a member of a union. By the deadline, 103 teachers had participated in the questionnaire. Of this number, $72(70 \%)$ were women and $31(30 \%)$ were men. They represented various age groups, but a majority were between 40 and 59 years old. A majority $(\mathrm{N}=96 ; 93 \%)$ had a higher education degree. In sum, they were representative of the basic target group of Finnish VET teachers by gender, age, and education (see Penttinen \& Portin, 2017).

The electronic questionnaire included questions about their backgrounds and about enthusiasm that were relevant to the research questions for this study. The first questions estimated how the VET teachers would evaluate their level of enthusiasm at work. For example, they were asked to evaluate how enthusiastic they were about their work with the Likert-scale of 1 to 4 ( $1=$ not at all enthusiastic ...4=very enthusiastic). They were then asked to describe, in their own words, their perceptions of how enthusiasm was manifested (if at all) in their work. In addition, we wanted the teachers to describe the factors that increased and decreased enthusiasm. They were asked open-ended questions about the ways that enthusiasm was manifested in their work, the factors that increased their enthusiasm, and the factors that decreased it. There was no limit on the length of the answers, so the teachers could write freely.

The analysis followed the principles of qualitative content analysis as the data were summarized, conceptualized, and re-structured. This was followed by the creation of various categorizations and classifications (Basit, 2003; Hsieh \& Shannon, 2005; Morse \& Richards, 2003; Thomas, 2006). The data analysis was performed by using Excel to distribute the answers to each question into units of analysis and relevant categories (Basit, 2003; Thomas, 2006). Reduction was achieved by first omitting irrelevant content from the teachers' answers (Thomas, 2006). For example, "collaboration with teachers from various fields in the institution, collaboration with teachers of various subject" was reduced to "collaboration and work community." In the second phase, grouping, the reduced expressions were compared and regrouped based on the similarities and differences (Hsieh \& Shannon, 2005; Morse \& Richards, 2003; Patton, 2002). In the third phase, sub-categories were combined to create main categories. This was followed by abstraction, as the actual main result categories had been created (Hsieh \& Shannon, 2005; Morse \& Richards, 2003; Patton, 2002). The main categories are introduced in the Results section. 
When evaluating the data collection and quality of research, some factors are worth noting. The data were collected in two phases. This presumably evened out the changes that occurred in the teachers' enthusiasm levels during each study year. This can be considered as increasing the reliability of the study (Cohen et al., 2011; Francis et al., 2010). In addition, approaching teachers through multiple channels - open networks, organizations' intra networks, social media, and unions - might have strengthened reliability because this ensured that teachers from various VET institutions and teachers from around the country could participate in the study.

As a method, an electronic questionnaire makes the collection of even large amounts of data quick and efficient (Cohen et al., 2011). Electronic data are also easy to manage and analyze. However, this method has been criticized for its superficiality (Creswell \& Miller, 2000).

In this study, the open-ended questions were answered with mostly lengthy descriptions. Yet, some answers were only one word long, such as "supervisor" or "colleagues," resulting in a lack of in-depth information from the specific answers. From the perspective of this study, it was important to obtain information in the teachers' own words, and it was also important that the group of participants be large because the purpose was to understand and to conceptualize the phenomenon (Cohen et al., 2011; Cozby \& Bates, 2012; Hsieh \& Shannon, 2005). Naturally, the electronic questionnaire did not allow the researcher to observe these teachers' actual teaching and interaction styles; the researcher could only interpret the teachers' own descriptions of their actions in teaching situations. In addition, questionnaire research is challenging because people may interpret the questions differently (Cohen et al., 2011; Cozby \& Bates, 2012). When answering questions about how enthusiasm was manifested, the participants sometimes also described the outcomes of their enthusiasm. While this difference is not crucial from a practical perspective, connections between reasons and outcomes have to be defined and studied through carefully chosen methods and research designs (Kunter et al., 2008).

In this study, VET teacher enthusiasm was studied qualitatively through the teachers' own words (Cozby \& Bates, 2012). The participants were able to complete the questionnaire anonymously; therefore, they could trust that they would not be recognized by their answers. This meant that the participants could also provide even comments that were critical about their workplaces and work environments freely (see also Cohen et al., 2011). Still, it is relevant to discuss whether these teachers' descriptions provide information about the reality in their work units or in student encounters and whether students or colleagues perceived these teachers' enthusiasm in the same manner that the teachers described it (Keller et al., 2016). In sum, this research approach depends on the accuracy and relevance of participants' descriptions (Creswell \& Miller, 2000; Gagné \& Vansteenkiste, 2013). 


\section{Results}

\subsection{The Manifestation of Enthusiasm}

A majority of the VET teachers $(\mathrm{N}=93 ; 90 \%)$ reported that they were very or quite enthusiastic about their work. Only ten participants felt that their enthusiasm was minimal or missing. In all, the research participants expressed in many ways how their enthusiasm was manifested: willingness to develop their job and expertise, dedication to the job, good job performance, and positive emotions and well-being.

First, enthusiasm was manifested by the willingness to develop teaching and guidance skills to better meet students' individual needs. In addition, enthusiasm seemed to increase the desire to educate and to try new methods.

"I think all the time, how I could teach better, more clearly, and more concretely everything." (5)

"After this long career, I still do not perceive myself as stuck, but I always find energy to get excited about new ways of working." (25)

Enthusiasm also appeared as effort and dedication at work. This led to better performance, according to the VET teachers' descriptions.

"So you are not satisfied with the barely good enough, but you want to challenge yourself and your closest colleagues to do your best $100 \% "$ (1)

Effort and dedication also meant that teachers followed developments in their fields closely and wanted to use the newest research-based information and teaching methods. Enthusiasm appeared as aspiration to design and to implement teaching techniques in versatile and inspiring ways so that students would be encouraged and motivated.

"Even during free time, I (even unconsciously) plan future encounters with students and forthcoming courses, take notes [about ideas]." (37)

Enthusiasm manifested as positive emotions and joy at work. The VET teachers had viewed enthusiasm as a good mood, joyfulness, positivity, and enjoyment on the job. These positive states could last beyond the workday; therefore, enthusiasm was also considered to affect overall well-being as it extended to other areas of life. According to the VET teachers, considering their work meaningful and valuable increased their positive perception of work.

"[Twenty-three] 23 years and yet it has not felt like work. Every morning I want to go to school." (68)

"[It is] the force that keeps you going." 


\subsection{Factors Strengthening Enthusiasm}

The VET teachers named several factors that increased their enthusiasm most. These included students, a good atmosphere and positive interactions in the workplace, resources related to the content and the nature of the job, professional development opportunities, and success and positive feedback from others.

The most important source of enthusiasm at work was students and interactions with them. The VET teachers reported that they especially felt excited when seeing students learn and succeed. These events meant that they had succeeded in their work. Thus, students' enthusiasm, activity, and motivation were considered to increase teachers' own enthusiasm.

"When I see a student learn and comprehend things (especially something he or she has found difficult or repulsive). In other words, when I feel that I have succeeded in my work!" (12)

"Teaching is nice, and I notice that my enthusiasm has partly spread to students. I have also received direct feedback about it." (46)

Positive interactions and work atmosphere were considered crucial for enthusiasm. Interactions with colleagues and between supervisors and employees should be positive. According to the VET teachers' perceptions, their enthusiasm became stronger if they had likeminded co-workers or if they received support and encouragement from the work community for their development ideas. Sometimes, inspiring interactions and collaborative relationships can be found through networks, projects, and partnerships with workplace representatives.

"You can express your thoughts safely and are allowed to develop things together with others. Good conversations and that you have regularly time to discuss with your closest co-workers." (31)

The VET teachers also mentioned that certain factors that were related to the content and nature of their work inspired and maintained enthusiasm. These factors were autonomy, challenges, diversity, and versatility. New tasks, changing work, and digital innovations were regarded as inspiring and providing new opportunities to learn at work. Opportunities to learn on their own or to participate in in-service training to develop their expertise and to apply what they have learned to their work (e.g., in curriculum planning), were mentioned as important for enthusiasm.

"It is challenging to get rusty in this job." (10)

"The work is appropriately challenging and provides opportunities to learn more all the time." (29)

"Voluntary studying gives me joy and benefits at work."

The VET teachers also mentioned experiences of student success and positive feedback from students, colleagues, and supervisors. Personal experiences of their own success 
strengthened their belief in themselves as teachers, while positive feedback from others convinced them about the appreciation of their effort and expertise.

"All feedback and encouragement increase trust in your expertise and inspires to carry on." (52)

\subsection{Factors Weakening Enthusiasm}

The VET teachers named the following as the main factors threatening their enthusiasm at work: lack of resources and cuts in education spending, negative atmosphere and problems in workplace interactions, structural and functional issues at their institutions, poor supervision and management, students' challenges and lack of motivation, and lack of personal resources.

The VET teachers reported that teaching resources had become scarcer because of recent cuts in education spending. The number of contact hours had decreased, while class sizes had increased. This made the teachers feel inadequate as they could no longer provide students as much support and guidance as the students needed. In general, being rushed, not having enough time, and having to do more administrative work decreased teachers' enthusiasm on the job. Changes and cuts in the vocational education budget made teachers feel insecure and uncertain about the future of VET. They were worried about job stability. In addition, the changes seemed to create confusion, especially if the changes had not affected their work directly.

"My enthusiasm is weakened by-lack to time to use for teaching. Huge cutting of contact teaching. To learn a vocation, you need time for practicing and repetition." (82)

"No one is interested in your opinion [about the changes]." (31)

Whereas good interaction and atmosphere strengthened teaching, it was no surprise that negativity, pessimism, constant complaining, as well as lack of appreciation and positive feedback crushed enthusiasm. Difficulties in interaction and communication and lack of opportunities to share opinions with colleagues were factors that created a negative atmosphere at work.

'Colleagues' unwillingness and laziness, and indifferent attitude toward students" (16)

"Several other colleagues' wish to stick to traditional teaching methods." (63).

Organizational factors, including structure and management (such as hierarchy and rigidity) made the VET teachers lose their enthusiasm. At the worst, organizational factors did not create space for inspiration, learning, and the development of new teaching methods.

"Everybody does it like this' guidance" (1) 
Some VET teachers mentioned that work was poorly organized. Some teachers had deficiencies in their physical work environment (e.g., dull and impractical teaching structures, lack of new technology). Likewise, problems in management and supervision, lack of support, and ignorance were considered to decrease enthusiasm. The VET teachers also mentioned that students had various problems, e.g., life management skills and lack of motivation, that made their work as teachers challenging, especially because of the inadequate amount of time allotted for guiding and supporting students.

"Unmotivated students who do what they want, and come and go randomly..." (60)

\section{Discussion}

The research participants seemed to be VET teachers who described themselves as being enthusiastic about their work and wanted to talk about it (e.g., Seale, 1999). Of the 103 participants, 93 (90\%) described themselves as very or somewhat enthusiastic, while only 10 participants $(10 \%)$ were just a little or not at all enthusiastic. It must be noted that the findings might have been different if more teachers who were less enthusiastic had participated in the study (Francis et al., 2010). In this kind of research, the participants are usually different from those who choose not to participate (Dale, 2006). The VET teachers' answers were quite similar. All the main result categories covered dozens of teachers' perceptions. The main categories were all accounted for by the first 35 participants.

Next, we summarize the findings of this research at two important levels that emerged from the teachers' answers: (a) enthusiasm as the catalyst for improving teaching effectiveness and (b) positive emotions and social interaction as the foundation for enthusiasm.

\subsection{Teachers' Enthusiasm Serves as the Catalyst for Development of Teaching Effectiveness and Positive Emotions at Work}

Teachers described their enthusiasm as teaching and interaction styles and as the subjective experience of pleasure (emotional dimension) and enthusiasm about their subject areas and the act of teaching (cognitive dimension) (Keller et al., 2016; Kunter et al., 2011). Enthusiasm manifested itself as the wish and desire to develop their own work, teaching techniques, and expertise, and to participate in the development of their institutions (see also Bakker, 2011; Klusmann et al., 2008). The VET teachers were dedicated and wanted to perform well and efficiently (see also Demerouti, Bakker, \& Gevers, 2015), especially in teaching and other encounters with students. According to their descriptions, their enthusiasm led to "extra-role performance," which meant they were working beyond what was required (Demerouti et al., 2015).

When the VET teachers considered the manifestation of their enthusiasm, they referred to their enthusiastic teaching styles, which appeared to be creativity and pleasure in teaching situations. According to previous studies, (Frenzel et al., 2009; Keller et al., 
2016), students may find this kind of teaching style interesting and inspiring. According to the findings of the current study, teachers experienced enthusiasm especially in encounters and interactions with students. This finding is also supported by those of earlier studies on teacher enthusiasm (Frenzel et al., 2009; Kunter et al., 2011).

In addition, teachers described many experiences of joy and pleasure that were related to teaching situations and work with students (Keller et al., 2014; 2016; Kunter et al., 2008). The VET teachers in this study hoped that their enthusiasm about their field of VET would increase students' enthusiasm and appreciation for their vocations. Indeed, the results of previous studies indicate that enthusiastic VET teachers are important role models (Keller et al., 2016; Krapp, 2007; Long \& Woolfolk Hoy, 2006; Patrick et al., 2000; Patrick, Turner, Meyer, \& Midgley, 2003)., The teachers in this study had noticed that their enthusiasm was captured by the students (see also Bakker, 2011; Hatfield, Cacioppo, \& Rapson, 1994). It has been noted that an enthusiastic teacher can create a positive participatory learning atmosphere that may enhance students' motivation and learning (Frenzel et al., 2009; Keller et al., 2016; Kunter et al., 2013; Meyer \& Turner, 2006; Patrick et al., 2000; Pekrun, Goetz, Titz, \& Perry, 2002). This leads to positive and good learning outcomes because enthusiasm can help students to have the courage to seize new challenges and the confidence to set goals.

Often, positive emotions have been used for explaining the positive effects of enthusiasm (Duckworth, Quinn, \& Seligman, 2009; Frenzel, 2008; Frenzel et al., 2009; Pekrun et al., 2002; Zhang, 2014). Indeed, it seems plausible that effort, dedication, good job performance, and the development of the job and the individual's expertise are connected to the positive emotions aroused by enthusiasm (Mroz \& Quinn, 2013; Sekerka, Vacharkulksemsuk, \& Fredrickson, 2012). In other words, enthusiastic encounters with students and colleagues can engender positive emotions and again increase the likelihood of positive behaviors, such as positive and efficient development and increased work engagement (Klusmann et al., 2008; Long \& Woolfolk Hoy, 2006; Uusiautti, Määttä, \& Leskisenoja, 2017).

\subsection{Teacher Enthusiasm Comes from Positive Social Interactions}

This study showed that support in the work community, the quality of interactions, and a positive workplace atmosphere can increase enthusiasm. On the other hand, a negative atmosphere and interactions can decrease enthusiasm if teachers feel that they are not appreciated or being supported (see also Uusiautti \& Määttä, 2013). Enthusiastic colleagues inspire one another and accept new developmental ideas (see also Vähäsantanen, 2015). Lack of enthusiasm in the work community and negative attitudes toward developments were reported to weaken teacher enthusiasm. A good atmosphere and positive interactions have been found to increase work engagement (Bakker et al., 2007; Schaufeli, Bakker, \& Van Rhenen, 2009), enthusiasm, and vigor (Carmeli, Ben-Hador, Waldman, \& Rupp, 2009).

While students' personal difficulties and lack of motivation seemed to decrease teachers' enthusiasm to some extent, the VET teachers still named students as the main source of their enthusiasm (see also Hakanen et al., 2006). Students' and teachers' enthusiasm 
had a reciprocal relationship. The VET teachers noticed that their enthusiasm seemed to increase the students' motivation and study engagement, and the students' interest and motivation inspired the teachers. This positive reciprocal effect has also been noted in previous studies (Kunter et al. 2011; Pelletier, Séguin-Lévesque, \& Legault, 2002). Enthusiasm seemed to have a communal and process-like nature as other studies have suggested (Bakker \& Xanthopoulou, 2009; Zhang, 2014).

As predicted, lack of resources, budget cuts, and uncertainty and worry about the future of VET decreased the perceived enthusiasm in VET teachers. However, even in situations of uncertainty, management and supervision can strengthen enthusiasm (Uusiautti, 2013). As previous studies have shown, leaders or principals can enhance the enthusiasm of subordinates and teachers by providing resources, showing appreciation, encouraging participation, building trust, and allowing autonomy (Carmeli et al., 2009; Pyhältö, Pietarinen, \& Soini, 2012; Roth, Assor, Kanat-Maymon, \& Kaplan, 2007; Vähäsantanen, 2015) - in other words, providing the optimal workplace environment. Increased autonomy at work is an important factor in teacher enthusiasm (Gagné \& Deci, 2005; Roth et al., 2007).

\section{Conclusion}

In this study, teacher enthusiasm manifested itself in ways that can be assumed to improve the quality of education and well-being in the work community (see also Keller et al., 2016). Although every teacher is responsible for the atmosphere at work, supervisors have the opportunity to facilitate positive interactions and collegial support through the organization of the workplace (Schaufeli \& Bakker, 2004). Even though teachers were very enthusiastic, they faced challenges and difficulties. It is easier to cope with these situations and to find solutions if teachers have faith in their expertise and receive support from the work community. Enthusiasm may increase communality and the ability to cope with everyday stressful situations such as challenging student encounters and the insecurity related to changes in the nature of the job (Zembylas \& Barker, 2007).

Work, in general, including teaching, is characterized by continual change. If the atmosphere is positive and focused on opportunities for development, reforms can be more easily accomplished (Barker Casa \& Milton, 2012; Fredrickson, 2001). It is also important that teachers participate in planning and the realization of the changes in their work (Pyhältö et al., 2012; Vähäsantanen, 2015). Vocational education reform creates new exciting opportunities to develop and to expand teachers' expertise through collaborations and developmental projects (see also Vähäsantanen, 2015). Management's role is to mediate the change so that individual teachers and teams can perceive their work as being as clearly defined, having as much autonomy, and being as inspiring as possible (see also Pyhältö et al., 2012). There are thus many reasons why discussing ways to enhance teacher enthusiasm is important.

When the connection between enthusiasm and work engagement was analyzed, enthusiasm seemed to be specifically a manifestation of a positive work drive and dedication at work. Stairs and Galpin (2013) used the concept "positive engagement" to describe pos- 
itive work engagement and attitudes to work from the perspective of well-being. Positive engagement supports and produces well-being. Positive leadership and opportunities to use one's strengths at work support well-being, good job performance, work drive, dedication, and the willingness to develop skills and expertise (Stairs \& Galpin, 2013; see also Uusiautti \& Määttä, 2015). Enthusiasm can be inspired and maintained through relationships with leadership that are based on trust and appreciation and are focused on teacher autonomy and participation (Carmeli et al., 2009; Pyhältö et al., 2012; Roth et al., 2007; Vähäsantanen, 2015). In the changing VET, teachers will face complicated situations and must solve them together with others. This will require creativity and flexible thinking. which can happen only if enthusiasm and positive emotions prevail at work (Fredrickson, 2001; Fredrickson \& Branigan, 2005; Sekerka \& Fredrickson, 2013).

Changes in the workplace cannot be predicted or effected. Therefore, leaders and supervisors have an important role as buffers because they can make work at the personal or team level have as much clarity and autonomy as possible (see also Pyhältö et al., 2012). In a positive atmosphere, new opportunities and changes are easier to embrace (Barker Casa \& Milton, 2012; Sekerka \& Fredrickson, 2013). Moreover, it would be important that teachers participate in planning and executing changes in their work (Pyhältö et al., 2012; Vähäsantanen, 2015). The reforms in vocational education and training can offer teachers opportunities for professional development. Such opportunities seem to be important resources for teachers (see also Bakker \& Bal, 2010).

By focusing on resources and strengths. as well as on the mutual understanding about everyone's role in maintaining a positive workplace atmosphere, it is possible to maintain work engagement and enthusiasm even in the face of external demands and pressures for change (Bakker \& Demerouti, 2007; Bakker, Demerouti, \& Euwema, 2005; Bakker, Hakanen, Demerouti, Xanthopoulou, 2007). Enthusiasm and the related positive emotions and interactions can facilitate the more efficient use of existing resources (Bakker, 2011; Hobfoll, 2002; Sekerka \& Fredrickson, 2013; Xanthopoulou, Bakker, Demerouti, \& Schaufeli, 2009a). In sum, enthusiasm can become the force that changes the whole organization by strengthening well-being and the ability to embrace the changes (see also Fredrickson, 2001; Sekerka \& Fredrickson, 2013) that VET teachers are currently experiencing in their institutions.

This study was conducted in Finland; therefore, the cultural characteristics that may have influenced the results must be considered. It is important to analyze whether the findings would have been different had the study been conducted with VET teachers in the United States, Australia, or Eastern European countries. Enthusiasm as a positive experience is very personal; thus, (Keller et al., 2014) the ways in which it is expressed or interpreted and the factors influencing it can be contextual. For example, Stenlund's (1995) cross-cultural research showed that cultural norms for student behavior and teacher-student relationships regarding work enthusiasm manifested differently in teachers from different countries. Therefore, more research on enthusiasm in different cultures is needed to determine the validity of the construct "enthusiasm" in culturally diverse settings (cf. research on teacher self-efficacy by Klassen et al., 2009). However, these Finnish VET teachers' perceptions and experiences are an example of teachers' self-perception of the factors that enhance and decrease work enthusiasm. 
Enthusiasm is the sum of many factors, including teacher personality (Keller et al., 2014). People interpret work resources and demands differently, based on their own values, interests, and motivation (Tadic, Bakker, \& Oerlemans, 2013; Vähäsantanen, 2015). According to Kunter et al. (2008), teacher enthusiasm as a personality trait can be defined as a tendency to experience positive affect during teaching. The findings in this study are supported by previous international studies on teacher enthusiasm and work drive. Enthusiasm has been examined in various types of organizations, and the results have shown the positive influence of enthusiasm on productivity (Harter et al., 2002; Xanthopoulou et al., 2009b), customer service quality (Salanova, Agut, \& Peiro, 2005), and workplace well-being (Hallberg \& Schaufeli, 2006; Schaufeli, Taris, \& Van Rhenen, 2008). In sum, there are many reasons to assume that in vocational education institutions, the influence of teacher enthusiasm would be positive and would increase education quality and effectiveness.

\section{Future Directions}

Studies that combine the perceptions of teachers, students, and work communities could further increase our understanding of enthusiasm in its social framework. As enthusiasm also seemed to be closely connected to supervision and management, it would be important to study leaders' and supervisors' perspectives (see also Bakker, 2011; Stairs \& Galpin, 2013). Indeed, the next phase of the current research is a further analysis of the role of positive work environments and supervisors in teacher enthusiasm.

It seems that a development orientation was closely connected with teachers' descriptions of their enthusiasm. Therefore, it would be relevant to compare enthusiasm with related concepts, such as "thriving," that also include the dimension of learning (Spreitzer, Sutcliffe, Dutton, Soneshein, \& Grant, 2005).

More research is also needed on the connection between enthusiasm and workplace well-being and teaching quality (Kunter et al., 2011). In a time of major changes in VET, this theme is very topical. What kinds of processes occur if we assume that enthusiasm increases teaching quality (Frenzel et al., 2009; Keller et al., 2016; Kunter et al., 2008; 2011)? What does teaching quality mean specifically? Thus, it would be worth studying the influence of teacher engagement and enthusiasm on student graduation rates and employment opportunities. These are now measured in VET; therefore, it would be important to study whether the enthusiasm of the employees affects the productivity of VET institutions in the same way it seems to do in other types of organizations (see Harter et al., 2002; Xanthopoulou et al., 2009b).

\section{References}

Bakker, A. B. (2011). An evidence-based model of work-engagement. Current Directions in Psychological Science, 20(4), 265-269.

Bakker, A. B., \& Bal, P. M. (2010). Weekly work engagement and performance: A study among starting teachers. Journal of Occupational and Organizational Psychology, 83(1), 189-206. 
Bakker, A. B., \& Demerouti, E. (2007). The job demands-resources model: State of the art. Journal of Managerial Psychology, 22(3), 309-328.

Bakker, A. B., Demerouti, E., \& Euwema, M. C. (2005). Job resources buffer the impact of job demands on burnout. Journal of Occupational Health Psychology, 10(2), 170180.

Bakker, A. B., Hakanen, J. J., Demerouti, E., \& Xanthopoulou, D. (2007). Job resources boost work engagement, particularly when job demands are high. Journal of Educational Psychology, 99(2), 274-284.

Bakker, A. B., \& Xanthopoulou, D. (2009). The crossover of daily work engagement: Test of an actor-partner interdependence model. Journal of Applied Psychology, 94(6), 1562-1571.

Barker Casa B., \& Milton, L. P. (2012). Resilience at work. Building capability in the face of adversity. In K. S. Cameron \& G. M. Spreitzer (Eds.), The Oxford handbook of positive organizational scholarship (pp. 805-908). New York, NY: Oxford University Press.

Barsade, S. G., \& Gibson, D. E. (2007). Why does affect matter in organizations? Academy of Management Perspectives, 21(1), 36-59.

Basit, T. (2003). Manual or electronic? The role of coding in qualitative data analysis. Educational Research, 45(2), 143-154.

Carmeli, A., Ben-Hador, B., Waldman, D. A., \& Rupp, D. E. (2009). How leaders cultivate social capital and nurture employee vigor: implications for job performance. Journal of Applied Psychology, 94(6), 1553-1561.

Cohen, L., Manion, L., \& Morrison, K. (2011). Research methods in education. (7th ed.) London: Routledge.

Cozby, P. C., \& Bates, S. C. (2012). Methods in behavioral research. (11th Intl Ed.) New York, NY: McGraw-Hill.

Creswell, J. W., \& Miller, D. L. (2000). Determining validity in qualitative inquiry. Theory Into Practice, 39(3), 124-130.

Dale, A. (2006). Quality issues with survey research. International Journal of Social Research Methodology, 9 (2), 143-158.

Demerouti, E., Bakker, A. B., \& Gevers, J. M. P. (2015). Job crafting and extrarole behavior: The role of work engagement and flourishing. Journal of Vocational Behavior, 91, 87-96.

Demerouti, E., Bakker, A. B., Nachreiner, F., \& Schaufeli, W. B. (2001). The job demands - resources model of burnout. Journal of Applied Psychology, 86(3), 499512.

Denzin, N. K., \& Lincoln, Y. S. (2003). Introduction: The discipline and practice of qualitative research. In N. K. Denzin, \& Y. S. Lincoln (Eds.), The landscape of qualitative research. Theories and Issue (pp. 1-45). Thousand Oaks, CA: Sage.

Doldor, E., Silvester, J., \& Atewologun, D. (2017). Qualitative Methods in Organizational Psychology. In W. S. Rogers \& C. Willig (Eds.), The SAGE Handbook of Qualitative Research in Psychology (pp. 520-540). doi:10.4135/9781526405555

Duckworth, A. L., Quinn, P. D., \& Seligman, M. E. P. (2009). Positive predictors of teacher effectiveness. The Journal of Positive Psychology, 4(6), 540-547.

Francis, J., Johnston, M., Robertson, C., Glidewell, L., Entwistle, V., Eccles, M. P., \& Grimshaw, J. M. (2010). What is an adequate sample size? Operationalising data 
saturation for theory-based interview studies. Psychology and Health, 25(10), 12291245.

Fredrickson, B. L. (2001). The role of positive emotions in positive psychology. The broaden-and-build theory of positive emotions. American Psychologist, 56(3), 218226.

Fredrickson, B. L., \& Branigan, C. (2005). Positive emotions broaden the scope of attention and thouhgt-action repertoires. Cognition and Emotion, 19(3), 313-332.

Frenzel, A. C. (2008). Teacher emotions. In R. Pekrun \& L. Linnenbrink-Garcia (Eds.), International handbook of emotions in education (pp. 494519). London: Routledge.

Frenzel, A. C., Goetz, T., Lüdtke, O., Pekrun, R., \& Sutton, R. E. (2009). Emotional transmission in the classroom: exploring the relationship between teacher and student enjoyment. Journal of Educational Psychology, 101(3), 705-716.

Gagné, M., \& Deci, E. L. (2005). Self-determination theory and work motivation. Journal of Organizational Behavior, 26(4), 331-362.

Gagné, M., \& Vansteenkiste, M. (2013). Self-determination theory's contribution to positive organizational psychology. In A. B. Bakker (Ed.), Advances in positive organizational psychology. Vol. 1 (pp. 61-82). Bingley: Emerald.

Hakanen, J. J., Bakker, A. B., \& Schaufeli, W. B. (2006). Burnout and work engagement among teachers. Journal of School Psychology, 43(6), 495-513.

Hallberg, U. E., \& Schaufeli, W. B. (2006). "Same same" but different? Can work engagement be discriminated from job involvement and organizational commitment? European Psychologist, 11(2), 199-127.

Harter, J. K., Schmidt, F. L., \& Hayes, T. L. (2002). Business-unit-level relationship between employee satisfaction, employee engagement, and business outcomes: A meta-analysis. Journal of Applied Psychology, 87(2), 268-279.

Hatfield, E., Cacioppo, J. T., \& Rapson, R. L. (1994). Emotional contagion. New York, NY: Cambridge University Press.

Hobfoll, S. E. (2002). Social and Psychological resources and adaptation. Review of General Psychology, 6(4), 307-324.

Hsieh, H. F., \& Shannon, S. E. (2005). Three approaches to qualitative content analysis. Qualitative Health Research, 15(9), 1277-1288.

Josephson, M., \& Vingård, E. (2007). Zest for work? Assessment of enthusiasm and satisfaction with the present work situation and health - A 1.5-year follow-up study. Work, 29(3), 225-231.

Keller, M. M., Goetz, T., Becker, E. S., Morger, V., \& Hensley, L. (2014). Feeling and showing: a new conceptualization of dispositional teacher enthusiasm and its relation to students' interest. Learning and Instruction, 33, 29-38.

Keller, M. M., Neumann, K., \& Fischer, H. E. (2013). Teacher enthusiasm and student achievement. In J. Hattie \& J. M. Anderman (Eds.), Educational psychology handbook: international guide to student achievement (pp. 247-250). London: Routledge.

Keller, M. M., Woolfolk Hoy, A., Goetz, T., \& Frenzel, A. C. (2016). Teacher enthusiasm: Review and redefining a complex construct. Educational Psychology Review, 28(4), 743-769.

Klassen, R. M., Bong, M., Usher, E. L., Chong, W. H., Huan, V. S., Wong, I. Y. F., \& Georgiou, T. (2009). Exploring the validity of a teachers' self-efficacy scale in five countries. Contemporary Educational Psychology, 34, 67-76. 
Klusmann, U., Kunter, M., Trautwein, U., Lüdtke, O., \& Baumert, J. (2008). Teachers' occupational well-being and quality of instruction: The important role of selfregulation. Journal of Educational Psychology, 100(3), 702-715.

Krapp, A. (2007). An educational-psychological conceptualisation of interest. International Journal for Educational and Vocational Guidance, 7(1), 5-21.

Kunter, M., Frenzel, A. C., Nagy, G., Baumert, J., \& Pekrun, R. (2011). Teacher enthusiasm: dimensionality and context specificity. Contemporary Educational Psychology, 36(4), 289-301.

Kunter, M., \& Holzberger, D. (2014). Loving teaching: research on teachers' intrinsic orientations. In P. W. Richardson, S. A. Karabenick, H. M. G. Watt (Eds.), Teacher motivation. Theory and practice (pp. 83-99). New York, NY: Routledge.

Kunter, M., Klusmann, U., Baumert, J., Richter, D., Voss, T., \& Hachfeld, A. (2013). Professional competence of teachers: effects on instructional quality and student development. Journal of Educational Psychology, 105(3), 805-820.

Kunter, M., Tsai, Y., Klusmann, U., Brunner, M., Krauss, S., \& Baumert, J. (2008). Students' and mathematics teachers' perceptions of teacher enthusiasm and instruction. Learning and Instruction, 18(5), 468-482.

Lichtman, M. (2013). Qualitative research in education. A user's guide. Thousand Oaks, CA: Sage.

Long, J. F., \& Woolfolk Hoy, A. (2006). Interested instructors: a composite portrait of individual differences and effectiveness. Teaching and Teacher Education, 22(3), 303-314.

Meyer, D. K., \& Turner, J. C. (2006). Re-conceptualizing emotion and motivation to learn in classroom contexts. Educational Psychology Review, 18(4), 377-390.

Minedu. (2017). Reform of vocational upper secondary education. Retrieved from: http://minedu.fi/en/reform-of-vocational-upper-secondary-education

Morse, J. M., \& Richards, L. (2003). Readme first. A user's guide to qualitative methods. Thousands Oaks, CA: Sage.

Mroz, D., \& Quinn, S. (2013). Positive organizational scholarship leaps into the world of work. In P. A. Linley, S. Harrington, \& N. Garcea (Eds.), The Oxford handbook of positive psychology and work (pp. 251-264). New York, NY: Oxford University Press.

Patrick, B. C., Hisley, J., \& Kempler, T., (2000). "What's everybody so excited about?" The effects of teacher enthusiasm on student intrinsic motivation and vitality. Journal of Experimental Education, 68(3), 217-236.

Patrick, H., Turner, J. C., Meyer, D. K., \& Midgley, C. (2003). How teachers establish psychological environments during the first days of school: Associations with avoidance in mathematics. Teachers College Record, 105(8), 1521-1558.

Patton, M. Q. (2002). Qualitative research and evaluation methods. Thousand Oaks, CA: Sage.

Pekrun, R., Goetz, T., Titz, W., \& Perry, R. P. (2002). Positive emotions in education. In E. Frydenberg (Ed.), Beyond coping. Meeting goals, visions and challenges (pp. 149-173). New York, NY: Oxford University Press.

Pelletier, L. G., Séguin-Lévesque, C., \& Legault, L. (2002). Pressure from above and pressure from below as determinants of teachers' motivation and teaching behaviors. Journal of Educational Psychology, 94(1), 186-196. 
Penttinen, S., \& Portin, M. (2017). Ammatillisen koulutuksen opettajat [Vocational education teachers]. In T. Kumpulainen (Ed.), Opettajat ja rehtorit Suomessa 2016 [Teachers and rectors in Finland 2016] (pp. 85-107). Helsinki: National Board of Education Finland. Retrieved from:http://www.oph.fi/download/185376_opettajat_ja_ rehtorit_Suomessa_2016.pdf

Pyhältö, K., Pietarinen, J., \& Soini, T. (2012). Do comprehensive school teachers perceive themselves as active professional agents in school reforms? Journal of Educational Change, 13(1), 95-116.

Roth, G., Assor, A., Kanat-Maymon, Y., \& Kaplan, H. (2007). Autonomous motivation for teaching: How self-determined teaching may lead to self-determined learning. Journal of Educational Psychology, 99(4), 761-774.

Russell, J. A. (1980). A circumplex model of affect. Journal of Personality and Social Psychology, 39(6), 1161-1178.

Salanova, M., Agut, S., \& Peiro, J. M. (2005). Linking organizational resources and work engagement to employee performance and customer loyalty: The mediation of service climate. Journal of Applied Psychology, 90(6), 1217-1227.

Salanova, M., Bakker, A. B., \& Llorens, S. (2006). Flow at work: Evidence for an upward spiral of personal and organizational resources, Journal of Happiness Studies, 7(1), $1-22$.

Schaufeli, W. B., \& Bakker, A. B. (2004). Job demands, job resources, and their relationship with burnout and engagement. A multi-sample study. Journal of Organizational Behavior, 25(3), 293-315.

Schaufeli, W. B., Bakker, A. B., \& Van Rhenen, W. (2009). How changes in job demands and resources predict burnout, work engagement, and sickness absenteeism. Journal of Organizational Behavior, 30(7), 893-917.

Schaufeli, W. B., Salanova, M., González-Roma, V., \& Bakker, A. B. (2002). The measurement of engagement and burnout: A two sample confirmatory factor analytic approach. The Journal of Happiness Studies, 3(1), 71-92.

Schaufeli, W. B., Taris, T. W., \& Van Rhenen, W. (2008). Workaholism, burnout, and work engagement: Three of a kind or three different kinds of employee well-being? Applied Psychology: An International Review, 57(2), 173-203.

Seale, C. (1999). Quality in qualitative research. Qualitative Inquiry, 5(4), 465-478.

Sekerka, L. E., \& Fredrickson, B. L. (2013). Working positively toward transformative cooperation. In P. A. Linley, S. Harrington, \& N. Garcea (Eds.), The Oxford handbook of positive psychology and work (pp. 81-94). New York: Oxford University Press.

Sekerka, L. E., Vacharkulksemsuk, T., \& Fredrickson, B. (2012). Positive emotions. Broadening and build upward spirals of sustainable enterprise. In K. S. Cameron \& G. M. Spreitzer (Eds.), The Oxford handbook of positive organizational scholarship (pp. 168-177). New York, NY: Oxford University Press.

Spreitzer, G. M., Sutcliffe, K., Dutton, J., Sonenshein, S., \& Grant, A. M. (2005). A socially embedded model of thriving at work. Organization Science, 16(5), 537-549.

Stairs, M., \& Galpin, M. (2013). Positive engagement: From employee engagement to workplace happiness. In P. A. Linley, S. Harrington, \& N. Garcea (Eds.), The Oxford handbook of positive psychology and work (pp. 143-154). New York, NY: Oxford University Press. 
Stenlund, K. V. (1995). Teacher perceptions across cultures: The impact of students on teacher enthusiasm and discouragement in a cross-cultural context. Alberta Journal of Educational Research, 41(2), 145-161.

Tadic, M., Bakker, A. B., \& Oerlemans, W. G. M. (2013). Work happiness among teachers: A day reconstruction study on the role of self-concordance. Journal of School Psychology, 51(6), 735-750.

Thomas, D. R. (2006). A general inductive approach for analyzing qualitative evaluation data. American Journal of Evaluation, 27(2), 237-246.

Uusiautti, S. (2013). An action-oriented perspective on caring leadership: a qualitative study of higher education administrators' positive leadership experiences. International Journal of Leadership in Education: Theory and Practice, 16(4), 482-496. doi:10.1080/13603124.2013.770077

Uusiautti, S., \& Määttä, K. (2013). Does success at work produce well-being and happiness or vice versa? The International Journal of Interdisciplinary Organizational Studies, 7(3), 11-25.

Uusiautti, S., \& Määttä, K. (2015). The psychology of becoming a successful worker. Research on the changing nature of achievement at work. New York, NY: Routledge.

Uusiautti, S., Määttä, K., \& Leskisenoja, E. (2017) Succeeding alone and together. University students perceptions of caring online teaching. Journal of Studies in Education, 7(2), 48-66.

Uusiautti, S. (2017). Success at work requires hope and the ability to engage in an optimistic attitude. European Journal of Workplace Innovation, 2(2), 41-64.

Vähäsantanen, K. (2015). Professional agency in the stream of change: Understanding educational change and teachers' professional identities. Teaching and Teacher Education, 47, 1-12.

Vähäsantanen, K., Saarinen, J., \& Eteläpelto, A. (2010). Between school and working life: Vocational teachers' agency in boundary-crossing settings. International Journal of Educational Research, 48(6), 395-404.

Warr, P. (1990). The measurement of well-being and other aspects of mental health. Journal of Occupational Psychology, 63(3), 193-210.

Xanthopoulou, D., Bakker, A. B., Demerouti, E., \& Schaufeli, W. B. (2009a). Reciprocal relationships between job resources, personal resources, and work engagement. Journal of Vocational Behavior, 74(3), 235-244.

Xanthopoulou, D., Bakker, A. B., Demerouti, E., \& Schaufeli, W. B. (2009b). Work engagement and financial returns: A diary study on the role of job and personal resources. Journal of Occupational and Organizational Psychology, 82(1), 183-200.

Zembylas, M., \& Barker, H. B. (2007). Teachers' spaces for coping with change in the context of a reform effort. Journal of Educational Change, 8(3), 235-256.

Zhang, Q. (2014). Assessing the effects of instructor enthusiasm on classroom engagement, learning goal orientation and academic self-efficacy. Communication Teacher, $28(1), 44-56$.

Zhu, C., \& Engels, N. (2014). Organizational culture and instructional innovations in higher education: Perceptions and reactions of teachers and students. Educational Management Administration \& Leadership, 42, 136-158. 


\section{Biographical Notes:}

Sanna Wenström works as Education Coordinator at Luovi Vocational College in Oulu, Finland. She is a PhD student at the University of Lapland, Finland. Her research interests cover enthusiasm, work engagement, positive leadership and positive organizations especially in the field of vocational education and training.

Satu Uusiautti is a professor of education, especially educational psychology, at the University of Lapland, Finland. Her research interests cover positive psychology, positive development, human strengths and success at work.

Kaarina Määttä is a vice-rector and a professor of educational psychology at the University of Lapland, Finland. Her research interests cover teacher training and teacher development as well as positive psychology and love research. 